\title{
Sustainability and the politics of calculation: technologies of 'safe water,' subject-making, and domination
}

\author{
Laura Eichelberger ${ }^{1}$ \\ National Cancer Institute, USA
}

\section{Introduction}

Water insecurity is defined as long-term conditions of inadequate supply that lead to the reduction of water consumption necessary for healthy environments and community health (Whiteford and Whiteford 2005). With its oil wealth, an environment of abundant freshwater, and the largest coastline in the United States, Alaska is one of the last places one might expect to find water insecurity. But approximately one third of households in remote Alaska lack running water and sewers, and the majority of these are in Alaska Native villages. Many villages lack in-home water and wastewater systems entirely, and experience high rates of lower respiratory and skin infections (Hennessy et al. 2008; Wenger et al. 2010), as well as periodic epidemics (U.S. Congress 1994), cross-contamination from sewage, and diseases transmitted orally or through fecal contamination (Chambers et al. 2008, 2009).

The dominant lens through which the contributing factors and solutions to village water insecurity in Alaska has focused on the knowledge, attitudes, and behaviors of their indigenous residents. These problems have been attributed to an "indifference to the essentials of sanitation" (Buck and Hays 1943:9), a "primitive knowledge of hygiene and sanitation" and "cultural lag" (Alaska Department of Health 1957), and a need for greater community education and participation (Wiita and Haley 2003; Marino et al. 2009). Throughout, the solutions pursued have involved attempting to change the ways in which Alaska Natives understand water and health, and to restructure the social relations around these, most recently with an emphasis on community participation and accountability (Eichelberger 2011).

Today, village water and sanitation is understood by policymakers as an issue of economic sustainability in addition to, and sometimes rather than, one of public health. In the past three decades, studies have focused on identifying environmental and economic factors that hinder access to water and sewer services. These include high water tables, permafrost, seasonal flooding, the remoteness of villages, small populations that increase per household costs, limited cash economies, and poverty (Huskey 1992; EPA 1995; Berardi 1998b; Berardi 1999). In addition, studies have identified what are sometimes framed as local and cultural barriers, including cultural differences and miscommunications between agencies and communities, a preference for using local knowledge in choosing water sources, and the need for capacity building (EPA 1995; Wiita and Haley 2003; Marino et al. 2009).

The issue of village sustainability has become an acute one as energy costs rose dramatically across the state with the high price of oil over the last decade. The factors that carry the greatest weight in policy making around water and sanitation systems are those related to economic sustainability, not sustaining access to water. Full cost recovery for utilities and community accountability are now required by government funding agencies. When it comes to identifying obstacles to village sustainability, rarely are the ideas and practices around sustainability itself critiqued, nor the ways in which these contribute to water insecurity at the local level. Absent in most discussions are the larger historical processes of domination that have created the factors contributing to water insecurity, the same factors upon which a village's sustainability is now judged. Sustainability as a "problem" focuses on individual villages and individual behaviors, with the assumption that it can only be achieved through local accountability.

Sustainability has emerged in this context as an ideology in practice; a language that gives meaning to practices of domination around neoliberal ideals of accountability and cost recovery, rather than a goal of water security and public health. The ways in which sustainability is an ideology through which contemporary practices of domination operate are illustrated by the events surrounding a tribal council meeting I attended in the remote Iñupiaq village I call "Qimmiurat" in late January 2009. The council had convened to hear a presentation by a bulk fuel loan program that billed itself as a last chance for "at-risk" communities to achieve State of Alaska sustainability requirements. An adequate supply of fuel is required at multiple levels of the

\footnotetext{
${ }^{1}$ Dr. Laura Eichelberger, Cancer Prevention Fellow, National Cancer Institute, USA. Email: lauraeichelb "at" gmail.com. This work would not be possible without the generous support of many people who guided me along the way. Arriga, taikuu to all of my friends in Northwest Alaska for your immense generosity and kindness. Thank you to the many people working in public health, safe water, and local government who took the time to show me these complicated infrastructures. A tremendous thank you to my PhD committee at the University of Arizona for their mentorship and critiques: Dr. Linda Green, Dr. Mark Nichter, Dr. Mimi Nichter, Dr. Susan Shaw, and Dr. Thomas Perreault (Syracuse University). Thanks also to Dr. Anna Kerttula de Echave, and the generous support of the National Science Foundation (\#0713935), the Community Forestry and Environmental Research Partnerships, and the University of Arizona School of Anthropology. Finally, thank you to the anonymous reviewers of the Eric Wolf Prize committee for your invaluable feedback. Any errors and limitations of this study are my own. This paper appears in a JPE Special Section of Eric Wolf Prize papers edited by Joe Heyman.
} 
water treatment and acquisition process, making water security inseparable from energy security (Eichelberger 2010). Indeed, the rising costs and shortages of fuel were threatening the operations of water treatment facilities across this remote arctic region.

If you can't pay back this loan," the program representative told the council, "the State is going to say, 'You're not a sustainable community and we're not going to invest here.' You'll start seeing funds dry up for capital projects.

The term "capital projects" refers broadly to community development projects, including construction that would provide much-needed water and sanitation services to water-insecure communities. This threat of the State of Alaska terminating funding for capital projects was a tangible one for Qimmiurat, one of many villages across the State that lacked a running water and wastewater system. A project that has endured more than thirteen years to construct a running water and sewer system had been stalled by funding shortages and conflicts between a multitude of public and private entities. Qimmiurat residents contend daily with hauling adequate water to their homes and cross-contamination from hauling "honey buckets," 5-gallon buckets lined with garbage bags that are used for toilets. In addition to providing running water to households, the project would decommission the village's centrally-located sewage lagoon that overflows into the community every spring when the river floods, spreading sewage throughout the village and cutting residents off from their only treated water access point.

The issue of sustainability renders such public health cases invisible, as illustrated by the comment by a visiting non-Native public health nurse regarding the possibility of terminated funding:

Well, that's the way the world works. Most of the species who have walked the Earth ended up extinct at some point. Look, if you were on a sinking ship with fifty people, and there was only room for forty on the rafts, who would you throw off? It's the same issue.

This allegory cuts through the silences surrounding the ways in which this particular ideology of sustainability plays out at the local level. As the public health nurse's comment so clearly articulated, the logic underlying the policies of "sustainability" pursued in Alaska can be reduced to the question of who should be thrown off the ship, left behind to sink or swim? In this paper, I focus on the history of this idea in the context of water security in rural Alaska Native communities, and how local residents come to participate in these practices and discourse of domination.

\section{Water and energy insecurity in Qimmiurat}

Qimmiurat is located in Northwest Alaska, a region that spans a vast area of sea coastline, rivers, tundra, and taiga, with the Brooks Mountain Range in the north, and the Seward Peninsula in the south (Figure 1). The specific ecology varies, save the following general similarities. The sun barely rises, if at all, in the dead of winter and barely sets in the summer. It is not unusual for winter temperatures to remain below $-40^{\circ}$ Fahrenheit $\left(-40^{\circ} \mathrm{C}\right)$ for weeks at a time, and can fall below $-60^{\circ}\left(-51^{\circ} \mathrm{C}\right)$. The bright summers are short and generally cool, but temperatures can reach into the $90^{\circ}\left(32^{\circ} \mathrm{C}\right)$ range in some areas. During "break-up," the melting period lasting approximately mid-April to June, the rivers can become choked with ice and debris. In many villages, the water during break-up is too turbid to treat, and some water treatment plants discontinue pumping and servicing the community. The region has historically experienced a higher incidence of diarrheal disease during this time, a problem that continues today.

With fewer than 25,000 residents, Northwest Alaska is home to the Iñupiat. The Iñupiat were historically semi-nomadic, with the caribou hunters of the interior region moving more frequently than the whaling peoples of the coastal regions (Spencer 1984). At the turn of the nineteenth century, missionaries and the U.S. Bureau of Education began establishing villages and encouraged the Iñupiat to settle by offering schooling and much-needed medical services. The majority of these villages are only accessible by small aircraft, snow machine, or boat.

Central to historical Iñupiaq kin relations was mutual interdependency, what many Iñupiat today would describe simply as "sharing." Exchanges of regionally-specific resources, such as caribou from the interior for whale blubber from the coast, enabled survival in a harsh climate and may have mitigated conflicts (Oswalt 1967; Spencer 1984; Chance 1990). Elders describe how collecting water was often a group activity that figured into their local economy of exchanges (Eichelberger 2011).

Today, many Iñupiat lament that people share less and less with each other. Over the past century, commodities have become central to Iñupiat communities. Sled dogs have been replaced by snowmobiles, kayaks with motorboats, and whale- or seal oil lamps with electric lights. Household bills, including as much as \$250 per month for water and sanitation services (Eichelberger 2010), have contributed to this decline in sharing. Yet in times of scarcity, those with extended kin networks are able to benefit from the continued 
value placed on sharing. This is evident in the experiences of households that suddenly find themselves water insecure and must rely on kin to access limited amounts of water (Eichelberger 2010).

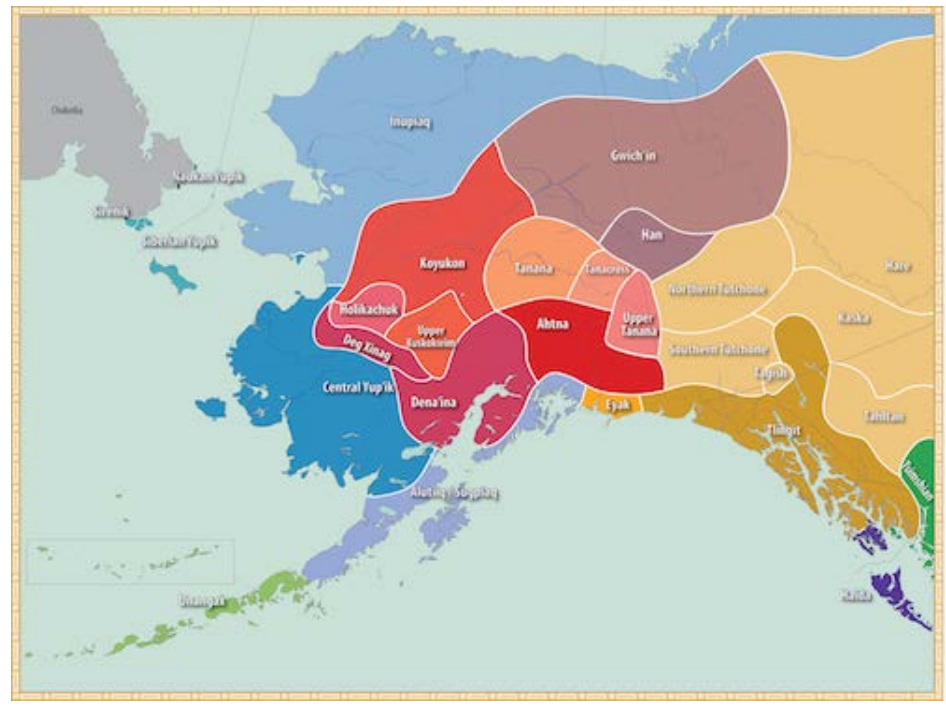

Figure 1: Indigenous Peoples and Languages of Alaska (Kraus et al. 1982)

Qimmiurat is one of the one-third of Alaska Native villages that lacks in-home running water. The village has what is called a "self-haul" system, with a very limited number of residents benefiting from a "flush-haul" system. Those with "flush-haul" systems haul up between 200 and 400 gallons (909-1818 litres) of water stored in a tank attached to their home and accessed using an electric pump that supplies water to one or two sinks, a flush toilet, and a shower. Residents haul water they purchase at US $\$ 0.75$ cents per 15 minutes from the washeteria, a building that combines the water treatment plant, laundromat, and shower facilities. The rest of the community hauls water in containers ranging in size from 5-gallon (23 litre) "jerry jugs" to 32-gallon (141 litres) plastic trashcans with lids, weighting from 42- to 267 pounds (42- 121 kilos) each.

Daily water consumption averaged 2.4 gallons (11 litres) per person day in 2009 (Eichelberger 2010), far below the 13.2 gallons (60 litres) per person standard suggested by the World Health organization (Howard and Bartram 2003). Among the primary factors that determine household water consumption are: access to a vehicle, the ability to purchase gasoline, the availability of male kin to haul the water, and water storage capacity. This average consumption also varies seasonally as weather and environmental factors such as flooding can affect a household's access to water (Eichelberger 2010).

The city government hauls household "honey buckets," 5-gallon (23 litre) trash bags of human waste, to the new sewage lagoon located outside the village. However, these often break open while awaiting pick up, and cross-contamination is a major concern among community residents. This public health issue is shared by all villages lacking running water systems (Chambers et al. 2008; Chambers et al. 2009).

Like all remote Alaska Native villages, petroleum-based energy is central to survival, from heating their homes to obtaining water. In addition to needing gasoline to haul sufficient water, the availability of treated water (locally called "safe water") depends on the availability of energy (heating oil and electricity) for a water treatment plant, the single greatest consumer of energy in villages across the region (Eichelberger 2010). For at least a decade, villages across the region have been contending with extremely high energy prices . A sudden rise in energy prices at a time of decreased state subsidies plunged village utilities into debt, leading to depleted budgets for operations and maintenance at the managerial level, and decreased household funds available for purchasing water (Eichelberger 2010). Between 2000 and 2006 alone, utility costs in remote regions rose by 50\% (Saylor and Haley 2007). In 2003, rural households paid between $3.2 \%$ and 5.1\% of their incomes for water, sewer, and electricity services, over 2-3 times the figure for Anchorage residents despite the fact that rural households consume fewer of these resources (Colt, Goldsmith, and Wiita 2003). By 2006, the median share of income for utilities among the poorest $20 \%$ households in remote areas was 33\% (Saylor and Haley 2007).

Thus, residents in communities with self-haul systems have increasingly been faced with choosing between purchasing water or paying their household bills. Rationing water is common during times when households cannot access sufficient treated water to meet their needs, at a significant risk household and community health. In this context, the Iñupiaq value of sharing has carried continual importance, and its practice enables many living in water insecurity to access a limited amount of water (Eichelberger 2010). 
However, sharing stands in contradiction to the emergent discourse and practices of sustainability, which revolve around commodification, cost-recovery, and bill collections.

\section{Sustainability and the technologies of water, commodification, and calculation}

Sustainability is conceptually ambiguous and inherently political, embedded with assumptions of how social relations and social-environmental relationships should be transformed (Perreault 2009). Examining the notion of sustainability as an ideology in practice reveals the processes of domination working through it and the consequences of those processes. Ideology always exists in practice and with subjects (Althusser 2006). It masks the contradictions and conflicts that result from the processes that create the inequalities necessary in capitalist relations (Hall 1977; Sider 1988). Appearing to lack its own contradictions, ideology discursively erases the contradictions people experience when the conditions of poverty hinder their ability to meet cultural expectations by providing meaning to some social relations and meaninglessness to others (Sider 1988).

This perspective is useful for critically examining sustainability and the contradictions in which these Iñupiat find themselves: trying to maintain a local value of sharing, while engaged in practices that directly contradict that value. The activities of agencies involved in village water and sanitation are both practical (such as constructing water treatment plants, and teaching local administrators and water plant operators in the use of technology), but also ideological: promoting the dominant ideology of the state in its struggle for hegemony. I seek to examine how sustainability and the closely related argument for community participation constitute ideologies in practice that serve to make sense of processes of domination that fragment communities by restructuring social relations and creating unequal access to water.

Water is both natural and social, a hydrosocial resource that cannot be understood separate from the power relations shaping the social relations around its use, the ways in which it is signified, and the knowledge produced around this natural resource (Bakker 2002; Swyngedouw 2004). Water physically circulates through the environment, but it also circulates power and money at local, regional, national, and global levels. Monopolistic control of water occurs in tandem with social and political control, the centralization of decision-making, and hierarchical bureaucratic control (Swyngedouw 2004).

To study water as both social and natural is to make visible these political, economic, and ecological processes shaping its circulation, access, and control. By reconstructing the processes through which the practices around and knowledges about water are produced, one can identify and consider these in relationship to the power relations in which they exist (Swyngedouw 2004). Indeed, water is a central site to examine shifts in power relations and their geographic reach (such as when control of rural water becomes centralized in urban centers), for it is a vital resource around which these relations are rearticulated and reinvented (Giglioli and Swyngedouw 2008:396). The commodification of water is one example.

Early in the 20th century it was believed that providing equitable access to water as a "material emblem of citizenship," a resource to which citizens had a right to universal and equitable access and that was necessary for heath and economic growth was the domain of government (Bakker 2004:21). Providing water was believed to be unfeasible for private companies because of its multiple market failures, including difficulties in setting prices that would reflect all of the costs and benefits of treated water (Bakker 2004; Bakker 2007). Public investment in water infrastructure, furthermore, was a foundation for state authority and a subsidy to capital. The construction of these networked systems facilitated capital accumulation by enabling the conditions through which industrialization, urbanization, and agricultural modernization occurred (Bakker 2004; Swyngedouw 2004).

Seeing water as a commodity became a dominant paradigm guiding water policy in the late twentieth century. The fiscal crises affecting industrialized nations in the 1970s led to a reconsideration of whether the state's role should include providing water. As states underinvested in their infrastructures, they were increasingly unable to meet the demands of their citizenry for water in terms of both quality and quantity. This is known as the state failure thesis (Bakker 2004). The ideological framework through which the role of the state in water was understood now revolved around the belief that states had largely failed in their mandate to provide water. Market-based approaches increasingly became the dominant paradigm guiding water management under the ideological shifts of neoliberalism.

Neoliberalism looks to market transactions as the only pathway to improved social wellbeing, and seeks to incorporate all human activities within the capitalist market (Harvey 2007:3). In this context, the role of the state was increasing understood to be limited to creating and preserving the conditions necessary for practices based on private property rights, free market, and free trade. Under this paradigm, it is assumed that the market is more efficient and equitable in providing water (Bakker 2004; Budds 2004), and that encourages efficiency and conservation (Page 2005; Pearce, Willis, and Jenkin 2007).

This shift towards what Bakker (2004) terms market environmentalism, meaning the application of market mechanisms in water management, involves a reconfiguration of water supply from a service to citizens to a business model that emphasizes efficiency over social equity. Customers, no longer citizens with respect to water, are not entitled to water as a right. As a commodity, water must be purchased at a price that 
encourages efficient use. Consumers are evaluated by their willingness rather than their ability to pay for water (Bakker 2004), or at times by their "attitude" to pay (Pearce, Willis, and Jenkin 2007).

This ideological shift in water governance also involves portraying water scarcity as universal (Bakker 2004; Johnston 2005), and its commodification is depicted as a natural pathway towards efficiency and conservation (Budds 2004; Swyngedouw 2004). The seemingly natural commodification of water obscures the processes and social relations of domination and exploitation that characterize market-based societies (Swyngedouw 2004). That such a neoliberal approach to water governance might in fact decrease social equity without improving access to water seldom enters into policymaking (Budds 2004).

The construction of water as a scarce commodity, rather than a resource that is shared, undermines locally defined usage priorities and the meanings attached to water in favor of those determined by global markets. Johnston (2005) refers to this process as environmental alienation, a term that draws attention to the inequalities of power involved in the production of treated water (and its scarcity) through modern technology. Environmental alienation is a useful lens for understanding how water insecurity, modern technology, and the commodification of water intersect. Water insecurity can result from unequal power and social forces embodied in treatment and distribution technology (Whiteford and Cortez-Lara 2005). These create inequalities of power over the control and knowledge production around natural resources (Ullrich 1992; Yapa 1996; von Schnitzler 2008), and can make communities dependent on outside entities for technical information about the quality and capacity of local water sources. This inequality of knowledge renders local organization around water quality impossible (Whiteford and Cortez-Lara 2005).

Finally, technologies used to control water resources are a means of maintaining power (Giglioli and Swyngedouw 2008), and creating particular subjects who are made governable and disciplined through their use of the infrastructure (von Schnitzler 2008). Practices such as the collection of user fees and involuntary disconnections induce particular moral behaviors of citizenry, creating a relationship between state and citizen that revolves around the commodification of water (von Schnitzler 2008).

Thus, water treatment and distribution technologies should be considered in relationship to processes of domination that are rendered natural and unintentional through the ideology of sustainability and the depoliticizing effects of technology and development projects. Understanding the mechanisms of development projects, regardless of whether they succeed or fail in their stated objectives, are crucial for identifying how such projects can result in the reorganization of power and the decentralization of the state into local institutions and subjectivities (Agrawal 2005) - the human linkages through which power is asserted.

James Ferguson (1990) terms this the instrument effects of development projects that, although never their intentional goal, enable the expansion of state power by establishing bureaucratic structures that facilitate control. A development project involves an established set of beliefs and expertise around a community and its "problem," and through the course of its work establishes a bureaucratic structure that though not its stated goal - results in the expansion of state powers locally. The "powerful constellations of control" (Ferguson 1990:20) that result appear authorless and subjectless, as do the perpetual failures of these projects with which communities must cope.

Examining water treatment facilities as technologies of governance reveals how techniques of government are embodied in a multiplicity of organizations and actors that have as their principle objective human welfare, but who exercise power over others based on their claim to expertise in areas such as health, economy, and village development (Ferguson 1990; Mitchell 2002; Li 2007). Practices central to sustainability requirements and the operations of water treatment facilities can be considered part of the politics of calculation (Mitchell 2002) that enable the comparison of communities, establishing criteria from which the totality of economic relations can be simplified, evaluated, and manipulated. These establish administrative control through defining particular "truths" upon which expertise and interventions are based. Using this perspective, this paper will identify how individuals come to practice such techniques at the local level, and how failures and inaccuracies of information are central to the politics of calculation. Indeed, these processes may be more significant than whether development projects succeed or fail.

Critically considering community participation in this context reveals how domination can occur both from within and without around access to water. Community participation is often proposed as a strategy to manage water and encourage sustainable development (Elmendorf and Isely 1983; Stanley 1990; Allison 2002; Pearce, Willis, and Jenkin 2007; Marino et al. 2009). In general, the idea of community participation assumes that involvement of community members will promote local empowerment, but in fact such approaches often exclude those outside of the dominant power structure (Morrow and Hensel 1992; Nadasdy 2000; Cooke and Kothari 2001; Kohl 2002; Schofield 2002; Roncoli 2010). Indeed, as others have demonstrated, participation does not guarantee the improvement of life for the most vulnerable (Cleaver 2001), but it can involve the reassertion of power by those already in power (Kothari 2001; Kohl 2002).

Further, participatory approaches often involve participants entering into institutions and social relations through which the "community" is rendered visible, and thus more readily analyzed and intervened upon (Scott 1998; Cleaver 2001; Esteva 2003). In Australia, for example, scholars have suggested community participation in water management as a way of encouraging the adoption of a user pays system desired by the Commonwealth government and contested by Aboriginal peoples (Pearce, Willis, and Jenkin 2007). 
It is from these combined perspectives that I analyze the institutional arrangements of power involved in operating and maintaining basic utility systems as technologies of power, and consider how these shape Iñupiaq social relations and the processes of domination from within. However, my critical perspective on community participation should not be read as a call to abandon community involvement, or as an argument that treated water and sanitation are not critical infrastructures for public health in rural villages. Community participation seeks to address issues of village self-determination and tribal sovereignty, both of which are enormous concerns for Alaska Native communities (Berardi 1998a). Further, partnerships between communities and agencies have produced improvements in villages' capacity for the successful operation and maintenance of their water and wastewater facilities (Haley 2000).

Yet the problems of village sanitation and access to treated water remain, despite emphasis on community participation and ownership of these systems. The question is not whether communities should participate, nor whether sustainability is a laudable goal, but how unequal power relations structure participation, and how issues of sustainability are conceptualized and solutions pursued. It requires, therefore, an historical examination of structural power revealed through development; the historical, political and economic contexts of development projects and their attendant ideologies; and how these have shifted under neoliberalism.

\section{Water insecurity within the politics of dependency and sustainability}

Water insecurity persists across rural Alaska despite a tremendous amount of money that historically has been invested in addressing the problem. This is in part due to the combined effects of poverty coupled with the environmental challenges of engineering water systems suitable for arctic conditions, and expensive systems have fallen into disrepair (Berardi 1998b, 1999). Sustainability as it is understood in Alaska today emerges out this failure of development projects to produce lasting results, but it has also been shaped by the history of struggles emerging from processes of domination. Central to these struggles have been debates concerning the Federal government's responsibilities to its indigenous populations, framed as questions over Alaska Native dependency and self-determination. Throughout, these debates have affected water and sanitation projects and the ways in which water security, community participation, and local responsibility have been conceptualized.

The introduction of treated water and sanitation systems emerge out of decades-old efforts by the state to improve Alaska Native health through projects to create Western-style communities, values, and social relations (Chance 1990; Blackman 1992; Ducker 1996; Berardi 1999). Treated water, sanitation, and improved hygiene were considered vital to the survival of Alaska Natives, who state officials feared for much of the late nineteenth and early twentieth century would become extinct from the deleterious health consequences of contact (see Hooper 1881; Alaska Department of Health 1943). Missionary programs, such as the Eskimo Mothers' Clubs, sprang up to address such needs. These organizations tied hygiene and health to what it meant to be modern (and moral) American Christians (Blackman 1992).

Though the concerns existed over self-determination and whether programs were fostering dependency of the indigenous communities on the government, these did not appear to take center stage until the 1950s. During that time, the Eisenhower Administration and some in Congress sought to terminate the Federal government's special relationship with native tribes through several termination acts. Many of the advocates of termination policies believed that the Bureau of Indian Affairs (BIA) had fostered dependency among America's native populations, and that assimilating them into dominant society was the only way to cease this trend (Jorgensen 1996; Kunitz 1996; Bergman et al. 1999).

Forced termination officially ended in 1970 with President Nixon who believed that the policy had in fact been harmful where implemented, by causing suspicion among Native groups towards the government, and "excessive dependence on the Federal government" (Nixon 1970, quoted in Kunitz 1996: 1466). Instead, Nixon advocated for policies that would encourage self-determination without the loss of Federal support, which he affirmed was an obligation to the Native peoples as defined by treaties.

Nixon's policy statement was enacted through two pieces of legislation under the Ford Administration: the Indian Self Determination and Educational Assistance Act of 1975, and the Indian Health Care Improvement Act of 1976. These Acts codified tribal participation and reflected mounting community demands for control of Indian health services, hastened by the Civil Rights Movement of the 1960s (Kunitz 1996).

These self-determination policies, crafted at the same time that neoliberalism was beginning to gain ground, sought to end dependence through community participation, decentralization of Federal services, and through integration of indigenous populations into the mainstream economy (see also Jorgensen 1996). The Indian Health Care Improvement Act of 1976, which made the Indian Health Service (IHS) responsible for the construction of safe water and sanitary waste disposal facilities (U.S. Congress 1994), specifically stated a policy of maximum community participation in planning and management while also reaffirming the Federal responsibility towards tribes (Bergman et al. 1999).

The political cachet of self-determination reflects the increased stigmatization of dependency during a time of expanding notions of equality and citizenship to women and minorities following the Civil Rights 
Movement. Adults were no longer legally excluded from wage labor, and thus had no publicly-sanctioned reason to be dependents (Fraser and Gordon 1994).

In Alaska, the ideals of community participation and self-determination were woven into a project of integrating Alaska Natives into the dominant economy through property rights. This process culminated with a significant piece of legislation, the 1971 Alaska Native Claims Settlement Act (ANCSA) that sought to address the economic and social needs "with maximum participation by Natives and decisions affecting their rights and property" (ANCSA, Section 2(b), quoted in Case and Voluck 2002:168). The resolution of Native land claims through ANCSA was a critical condition that set the stage for the full development of the oil discovered in Prudhoe Bay and the construction of the Trans-Alaska Pipeline (Dombrowski 2001; Mitchell 2001), ushering in Alaska's modern petrol-economy (McBeath and Morehouse 1994).

An explosion of development projects occurred during this period, including the construction of village water treatment plants and 'washeterias' following the passage of the Village Safe Water (VSW) Act in 1972, which created a program by the same name. The original objective of VSW was "to provide safe water and hygienic sewage disposal facilities in villages in the state" that would "be available for use by the public and...designed to assure year-round use" (State of Alaska 1972). The legislation made the commissioner of the newly created Alaska Department of Environmental Conservation (ADEC) responsible for ensuring that each village had at least one such facility, with the power to provide grants for the operations and maintenance of these systems. The Act also placed responsibility for facility operations and maintenance squarely on the village governing body, stipulating that construction would not occur without "satisfactory assurances...that it will, upon completion of a facility, accept ownership and responsibility" (State of Alaska 1972).

Following the construction of the oil pipeline in 1977, the State of Alaska began funding water and sanitation projects at significantly higher rates than before, owing to the sudden rise in revenues from oil production (Figure 2). In 1982 taxes and royalties from oil production made up 85 percent of state revenues, and state aid for local government operations had almost tripled from 1980. The Alaska Legislature increased municipal public works funding from a few million to almost half a billion dollars. Indeed, the State of Alaska met or exceeded federal spending levels for water and sanitation projects between the fiscal years of 1984 and 1994 (Figure 2). According to data from the State of Alaska Village Safe Water Program, by 2009, both the state and federal government had spent almost two billion dollars on rural water and sanitation projects since 1960. This huge influx of state capital enabled rural growth, including services and projects that needed a larger body of administrators employed by the cities, and which would otherwise have been unaffordable in communities with limited tax bases (Leask 1983; McBeath and Morehouse 1994).

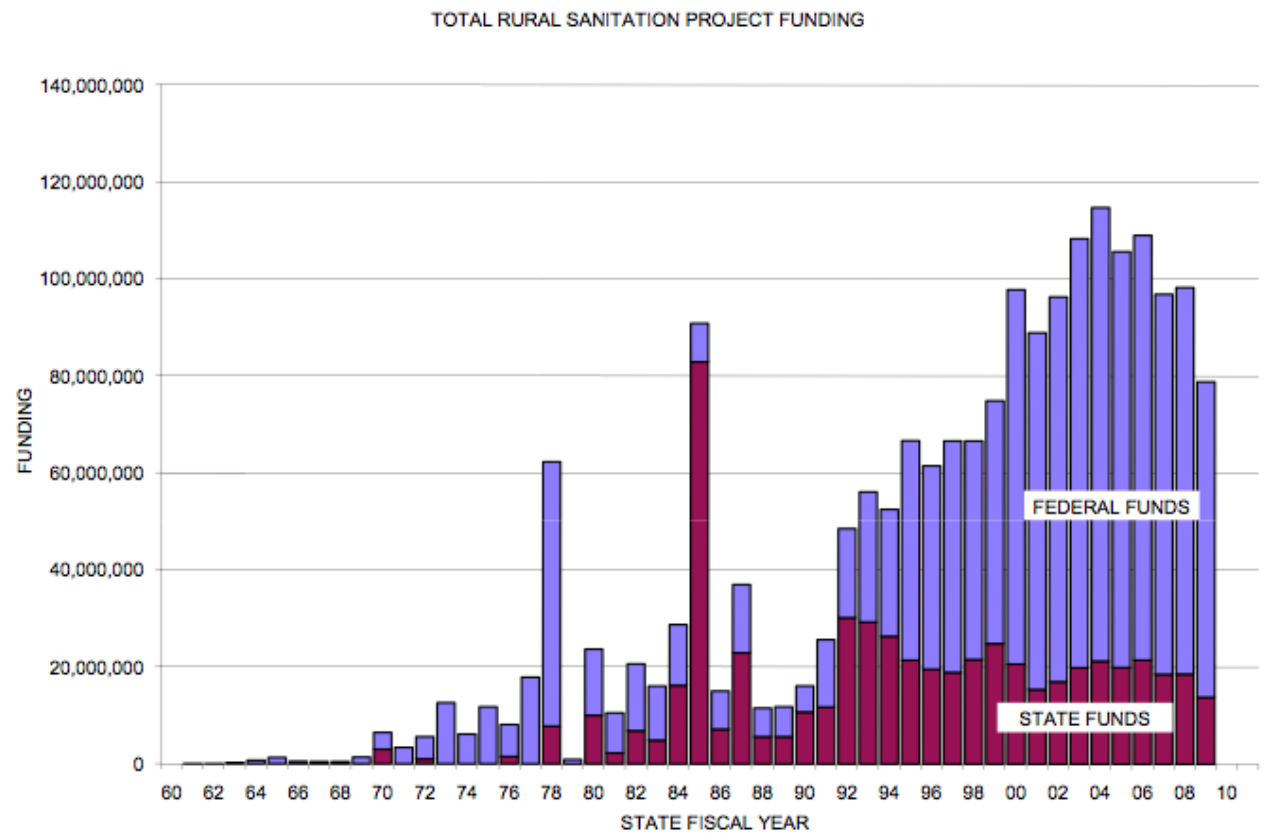

Figure 2: Total rural sanitation project funding (FY 60-09, US\$). Source: Village Safe Water.

One unanticipated consequence of these development projects was the emergence of rural services and governmental bodies dependent on revenue transfers from the State. The influx of capital investment, 
combined with the decreased mortality rates from treated water (U.S. Congress 1994) led to an increase in village populations. Alaska Natives, who had been migrating out of villages in the 1950s and 1960s, began moving back into remote communities partially to qualify for Native corporation membership under ANCSA (and thus corporate dividends), and in part because of the new availability of employment and public services supported by the transfer economy (Leask 1983; Kruse and Foster 1986; Berardi 1999). At the same time, the transfer economies of rural municipalities that resulted from this sudden growth in government (including employment) became dependent on these subsidies for their operations (Leask 1983; Knapp and Huskey 1988).

Environmental factors characterizing Arctic villages compounded their financial dependence on the revenue transfers for services such as water and sanitation. From the beginning, safe water projects encountered environmental factors that intersected with political and economic ones to create significant challenges. Missionaries, backed by the U.S. Bureau of Education, did not establish the villages in areas conducive to the types of technologies later introduced to treat and distribute water that coincided with the growth of these populations (Berardi 1999).

The original safe water infrastructures were not designed to withstand arctic conditions, and their failure to provide dependable treated water without additional and expensive upgrades eventually led many policymakers and residents to wonder what the point was of all that investment. Indeed, the Alaskan arctic appears to have been a laboratory for experiments in cold weather engineering during the Cold War (see American Public Health Association 1984; Fortuine 2006). In interviews, both village residents and regional leaders described how visitors seemed to show up suddenly in their villages encouraging expensive experimental infrastructure projects. Village councils had to approve the plans, usually without the local expertise to do so. In many cases they had few choices and little substantive input if they wanted any system at all. Local accounts indicate the current problems villages have in affording the operation and maintenance of these systems stems in large part to the poor experimental designs of the 1970s and 1980s.

The first guy they sent up didn't know what he was doing. I have lines outside my house that go like this." He gestured in the air, making sharp angles with his hand to illustrate the rightangled arctic piping snaking across the village. "There were supposed to be only eleven, but we got twenty five. It causes freeze-ups.

-- Male elder head of household

These poorly designed systems are the reason for system failures and high O\&M [operations and maintenance] costs. Couple this with very little consideration given to innovative, cost saving (alternative energy) when these systems were initially designed, so wonder we can't afford to support these systems.

-- Iñupiaq regional leader (email to author)

Villages continue to struggle to afford the expensive operations, maintenance, and repair of water and sewer infrastructures that are subject to harsh seasonal conditions, including extremely cold temperatures, flooding, and high turbidity that require a greater level of treatment.

As Alaska's economic boom from the pipeline declined in the late 1980s with falling global oil prices, official discourse on water scarcity took on a different tone. Despite the investments made in rural development, by the mid-1980s it became clear that employment opportunities within villages were not growing enough to support the population and the local governing bodies through taxation (Leask 1983; Kruse and Foster 1986; Knapp and Huskey 1988). Also increasingly clear was the fact that rural communities would not be able to afford the operations and maintenance of these expensive systems without government financial assistance.

The right to water and sanitation infrastructure, once pursued as part of transforming Alaska Natives into a proper hygienic citizenry (Berardi 1999), was thrown into question.

[O]ne can imagine a more satisfactory policy which continues to provide some level of basic services, but which encourages those who want the equivalent of urban services in rural communities to lower their expectations or move to urban Alaska (Kruse and Foster 1986).

Economists argued that the prevailing idea that clean water, housing, and adequate health care were basic human rights were behind the growth of state support for rural villages that led to the existence of a population three times as high as that which could be supported at the existing per capita income level (Knapp and Huskey 1988). They argued that the notion that such basic infrastructure is a human right is significant "because rights are not limited by costs" (Knapp and Huskey 1988: 33). 


\section{Calculation and subject-making within the politics of sustainability}

It is against the historical backdrop of struggles over self-determination, fluctuating oil prices, rising energy costs, and the deterioration of expensive infrastructure that full cost recovery and village accountability have become the dominant criteria in water and sanitation projects, framed as an issue of sustainability requiring community participation. In this section, I examine the micro-processes of calculation and subject-making occurring through "community participation" and "capacity-building" under sustainability policies, by looking at the specific ways in which subjects are shaped into participants such that their actions and thinking reflect this move towards commodification, something that they themselves often oppose.

Community participation around village sustainability, sometimes phrased as "capacity building," includes promoting and enforcing the commodification of safe water. Local residents become engaged in the practices of calculation, determining and reporting rates of payment, measuring household accountability in ways that violate the local value placed on sharing. Struggles around water security, including the consequences of forced disconnections and underfunded village water projects, disappear under this discourse of sustainability that renders natural both the commodification of water and related processes of domination. In this way, community participation is part of the processes of domination from within that occur through water and sanitation technologies.

In this context, the Iñupiaq value of sharing is a hindrance to achieving state-defined sustainability, and the struggle between the two ideologies plays out at the local level. Some of the same people who lamented what they saw as a loss of sharing, and who at times argued against increasing user fees or charging for water at all, also occupied positions central to the processes around sustainability. In many cases, those involved in the management of the utility lived in water-insecure households or worked in offices without running water. Some could not afford to purchase adequate water for their households, or were behind on paying their water bills. Others lived in houses that either were disconnected from the system or were never connected when it was first installed.

While struggling to find ways to access sufficient water, these individuals were also involved in the micro processes of calculation: counting up the numbers of households delinquent on their water and sanitation bills, bill collections, and forced disconnections of households. These accountability practices play a large role in the allocation of limited water and sanitation project funds, for which villages compete, by comparing communities using standardized data.

Whereas the state initially constructed water treatment facilities and washeterias as part of a successful push to improve Alaska Native health through safe water and sanitation, today economic criteria and "local capacity" reign supreme in the allocation of project funding. Government agencies undertake projects based on a quantitative evaluation of community-specific "sustainability indicators" assessed by the Rural Utility Business Association (RUBA), while the village prevalence of water-washed diseases goes largely uncalculated.

Initially designed in 1990 as a program to assist villages in financial management and the operations and maintenance of their utilities, between 2002 and 2009 (when I completed my fieldwork) RUBA's mission increasingly emphasized performance evaluation in tandem with management assistance (Wade, Modrow, and Kane 2007). The RUBA Assessment is an evaluation of utility management practices by standards RUBA calls "essential" and "sustainable indicators." These indicators revolve around local capacity to manage the utility, particularly its financial and maintenance needs, and reflect the definition of sustainability codified by Administrative Order 224 (AO 224) signed into law by Governor Frank Murkowski on January 28, 2005:

Sustainability, by definition, includes all costs associated with management, operation and maintenance, renewal, and replacement (after the design life has been achieved) necessary to maintain an acceptable level of service.

As defined by AO 224, this definition of sustainability encompasses principles of low cost, standardized infrastructure, capacity building through management training, the establishment of a business plan that includes cost-recovery mechanisms, and requires that "user rates and fees should be assessed to cover all costs necessary to maintain sustainability" (Murkowski 2005).

RUBA Assistants assess communities in terms of economic criteria and management capacity, evaluated in part by adherence to federal water quality standards and whether the community is on the Significant Non-Complier (SNC) List. The SNC List is primarily an evaluation of the water plant operator's performance that RUBA uses as a measurement of the competence of the water plant operator and the utility's capacity for sustainability. The quarterly updates of RUBA assessments, as well as the SNC List, are posted online. Together, they create a public review of the accountability practices of rural - primarily Alaska Native - peoples, both as individuals and as governing bodies. Anyone familiar with the specific communities knows exactly to which individuals (the administrators, water plant operators, mayors and vice mayors) the RUBA assessment refers. 
The RUBA Assessment along with the SNC list are part of what one RUBA manager described to me as a "suite of information" agencies use to determine funding. According to VSW, one of the principle agencies involved in village water and sanitation projects:

The applications are scored, based heavily on the proposed project's ability to address assessed critical public health needs, as well as the communities' demonstrated capacity to operate and maintain the facilities...Local capacity is a vital component of developing sustainable sanitation systems throughout rural Alaska. Construction is only approved once communities have met agreed upon performance criteria and have demonstrated the capacity to operate and manage sanitation facilities. (Village Safe Water 2005)

Thus, becoming "RUBA compliant" is a major concern shared by the village governing bodies. Although this policy officially states that public health needs are taken into account, in practice the criteria used to determine the funding of a project remain a grey area in which project managers may pursue multiple courses trying to secure sufficient funding for projects, or they may discourage communities from pursuing costly construction. Throughout, agencies must frame their activities in terms of sustainability and pursue mechanisms of accountability in order to achieve any aspect of their mission and the survival of their institution.

There are several factors that I suggest give economic criteria greater weight than public health needs in the final distribution of funds. First, although several recent studies have demonstrated the relationships between in-home water service, sanitation, and health in rural Alaskan villages (Hennessy et al. 2008; Chambers et al. 2009; Wenger et al. 2010), generally individual village population sizes are too small to undertake many epidemiological studies necessary to demonstrate the relationship between water service levels and the local health concerns of a specific village. In contrast, economic assessments of specific villages are conducted on a regular basis, providing data that ends up having more weight in the decisionmaking process. This might explain why Qimmiurat leaders would struggle for well over a decade to secure funding to make progress on their piped water and sewer project. Despite the persistent water insecurity earlier described, they have a difficult time substantiating local health concerns to the entities in charge of projects. They lack the locally specific data that would enable their participation in these politics of calculation, which require sufficient standardized data by which community needs can be evaluated and compared.

Second, government data upon which project applications are based is often incorrect or incomplete, so the more easily tracked economic criteria end up having more weight in the decision-making process. However, the accuracy of any data is questionable, in part because some RUBA assessments currently used are beyond their two-year lifespan while their quarterly updates (available online) rely on self-reported data from communities that may be inaccurate. The high turnover of administrators and water plant operators creates gaps in records. In addition, many of RUBA Assessments and project proposals I read through contained inaccurate data reporting lower monthly user fees charged for water or, in the case in Qimmiurat, significantly overestimating the number of households with flush-haul systems.

Such inaccuracies seem contrary to a system of governance based on calculations, but in fact accuracy is not important to the politics of calculability (Mitchell 2002). What is more important to the process is creating a particular truth about a specific village from which different communities can be compared and on which to base the allocation (or denial) of funds.

Indeed such inaccuracies are useful for the state as well as for those resisting commodification. Inaccuracies and incomplete information provide a modicum of wiggle room for project managers to navigate policies that often make little sense when implemented on the ground. They open spaces of non-control where functionaries in state agencies and local leaders (conceived of as community participants) can conceal information or perform behind-the-scenes actions without threatening their access to resources (Scott 1985). Yet they also enable the state to represent its work as successful, thus resulting in responsibility for the failures of these projects resting solely on the villages. The protracted delay in finishing Qimmiurat's piped water and sewer project has a two-fold effect: justifying further government and private involvement that makes the project more costly.

Despite these inaccuracies, RUBA Assessment standards are increasingly a major component in project funding. One of the RUBA sustainability indicators requires that water utilities demonstrate an 80 percent collection rate on water/sewer fees that during my fieldwork were as high as $\$ 150$ per month. This collection rate is financially impossible in many remote Alaska Native communities where populations are very small, unemployment is high, permanent employment options are limited, and gasoline can cost as much as $\$ 10$ per gallon. Communities that fail their RUBA Assessment are in a poorer position to receive funding for projects, creating local incentive to disconnect non-paying customers.

\footnotetext{
2 A RUBA Assistant brought both of these points to my attention.
} 
RUBA's activities around its original objective of capacity building accorded with local desires to maintain modern infrastructure associated with better health. They also establish the social relations necessary for the operation of water treatment systems and the practices of calculation occurring through safe water. Working almost exclusively with city governments (though some tribal governments that manage water and sewer utilities are involved), RUBA Assistants help the administrators, clerks, and utility managers try to meet these sustainability indicators and manage the economic demands associated with village infrastructures through training activities and village visits. They help the governing bodies balance their books, pay off debts, and submit the required annual Certified Financial Statements to the State of Alaska. They also periodically hold trainings in larger "hub" villages to teach city administrators, clerks, and utility managers (all predominantly women) how to use the modern technologies of accounting: computers and QuickBooks software. These sessions, along with water plant operator trainings co-sponsored by various environmental health agencies, have the objective of the successful operations and maintenance of these very expensive infrastructures. Throughout, they render the problem of village sustainability (and poverty) both technical and cultural, in need of capacity building and a change in the way the Iñupiat value water.

RUBA trainings center on the themes of achieving economic sustainability through accountability mechanisms, and are one site where neoliberal ideals are promoted and bureaucratic social relations are produced and deployed into the community. At the RUBA Utility Clerk training I attended, this occurred in tandem with the construction of water as a commodity. For four days in July 2008, seven female clerks and administrators, five trainers, and two observers (including myself) packed into a small classroom in a technical school along the beach at the edge of a village I call "Quag aq." To maximize their productivity, the all-female group of clerks and administrators were instructed to place professional responsibilities ahead of familial and cultural obligations. They were encouraged to use "FAQ" (frequently asked questions) handouts rather than interact with people directly so as to reduce interruptions at work. They were also told how to use and behave on the phone, how to create and use schedules, and the importance of delegating tasks.

Throughout the workshops, the trainers emphasized the importance of treating water as an economic good as part of cost recovery practices. They tied this imperative to the future funding of vital community projects and the survival of villages as a whole. In a lesson on financial management, one trainer wrote on the dry-erase board: "Providing water/sewer service in rural Alaska is . He asked the attendees to fill in the blank. A couple women wrote down "a necessity" and "important." Three women, including the clerk from a "honey bucket" village seeking funding for their piped water and sewer project, wrote down "expensive."

The trainer, a non-Native man who hailed from Anchorage, said that the answers he was looking for were "expensive," "very expensive," and "not cheap." He explained that water and sewer in the villages is expensive because no one can make money on it. Interestingly, his narrative moved between conceptualizing water as commodity and as commons, a struggle I found evident in the narratives of local leaders as well, revealing that even state agents struggle to find a cohesive frame for water even during efforts to commodify it.

If it was cheap or lucrative, a private company would have come in to do it. It's not there to make money on it, but it's tough to get the revenue to cover the expenses. It's important to collect fees because you need to pay for your bills as City or Tribal clerks or water/sewer owners... Water/sewer utilities are operated as an enterprise, a business. You have to collect money from people for it to function. But water/sewer is provided by the government, not as a business. You want to provide the best level of service that your residents can afford. Everyone wants to have good water and sewer. Your job as a public utility is to provide that at a cost they can afford.

As a bridge to a discussion on how to enforce collections, the trainer projected a cartoon on the board of children at a restaurant who have ordered food but do not have any money to pay for their meals: "We don't expect to get everything, we just want it." In the context of the training, this cartoon delegitimized the idea of water and sanitation as a right, at the same time that it portrayed those who contest its commodification as immature. $\mathrm{Li}$ (2007) has noted that framing populations as immature is used to justify the lack of investment in community development.

He then led the students in an accounting exercise to familiarize participants with each of the categories that must be included in city budgets as regulated by the State of Alaska. The subsequent discussion defined each of the accounting categories, including "enterprise funds" - revenues gained from providing services for price - which the trainer clearly tied to the issue of cost-recovery:

\footnotetext{
${ }^{3}$ Other programs include the Remote Maintenance Worker program, managed through the regional tribal health corporation, that sends a local individual (during my fieldwork only men) with experience in the operations and maintenance of various water plants and systems to the different villages to assist them with their operations and maintenance.
} 
This is what you should be doing with water/sewer: general revenue so it pays for itself. This is not a service provided for free. The reality is that sometimes it is provided for free, but it shouldn't be. You don't want to overcharge, but you need money to pay for water-sewer services.

RUBA trainers emphasized that both state and federal agencies increasingly were requiring villages to demonstrate fiscal responsibility and economic sustainability. One of the trainers noted that cutting off nonpaying customers is a critical element of achieving the RUBA sustainability indicators, but this strategy comes with a hidden cost.

The theory is that at some point, you have to cut off non-payers and then you'll have a $100 \%$ collection rate, but it doesn't really work that way. If they're not making payments, then you're losing money.

As the trainer's statement indicates, the reality of this policy is that a lower customer base means higher fees for remaining customers, putting at risk their ability to pay for services, and increasing health risks at household and community levels. Administrators and councils in communities where customers were not paying for services or with lower customer bases are encouraged to raise rates to make up for these lost revenues.

\section{Conclusion}

This paper has examined "sustainability" as an ideology of domination as it functions through the practices and subjectivities involved in the operations of water and sanitation infrastructures in Iñupiaq villages. The ways in which sustainability is defined in this context reflects historical struggles emerging from a history of domination, while participatory approaches to water development and management are mechanisms through which village residents come to participate in the processes of domination. Though paying for water is something largely contested at the village level, the energy crisis and experiences of water insecurity have facilitated this process, and individuals at the local level have become increasingly drawn into water's commodification through the creation of subjectivities around sustainability and accountability.

The issue of cost-recovery erases community experiences of water insecurity and renders moot the struggle between sustainability and sharing, by tying the commodification of water to the survival of the villages. In the neoliberal logic of sustainability, reinforcing the idea of safe water as a valuable and scarce commodity and creating disciplinary mechanisms around payment are the only viable solutions for maintaining the operation of these systems. Cost-recovery as a mechanism for achieving the ambiguous yet appealing standard of sustainability depoliticizes the issue of charging for water, rendering inappropriate citizen demands for in-home piped water and wastewater services. This was illustrated by the cartoon used in the training of the money-less children demanding food.

State-defined sustainability criteria, particularly full cost recovery, are difficult (if not impossible) to realize. Yet the mechanisms through which they are pursued and their unintended consequences are highly significant. The failure of villages to achieve the benchmarks of sustainability - indeed the perpetual failures to achieve these -are convenient for promoting the processes of domination, namely the restructuring of social relations around the neoliberal ideals of the state. These failures are rendered technical (the need for more efficient technologies and capacity building) and depoliticized in a way that obfuscates the historical causes of sustainability as a "problem" and places responsibility on the community members and leaders. Further, perpetual failures provide the bases for the state to offer interventions that legitimize its authority (Li 2007), but also to withdraw support for public health infrastructures.

The construction of water treatment plants has facilitated - and even required - (intentionally or not) the concentration and reorganization of power and knowledge around technical expertise that exists outside of the community, and the creation of particular local subjectivities to enforce this reorganization of power. Today, rather than water and sanitation being a right of American citizenship, as discourses of the midtwentieth century portrayed it, access to "safe water" is increasingly the privilege of consumer citizenship (von Schnitzler 2008), tied to the successful demonstration at both household and community levels of accountability: on-time bill payments for households, and 80 percent fee collection levels for utilities.

The promotion of market principles to manage Iñupiaq access and use of safe water, and the administrative practices that enforce its commodification currently occur in a discursive field of crisis discourses and threats to the governing bodies and subject positions that emerged out of intertwining policies of self-determination and public health through water and sanitation infrastructure. Village governments, both city and tribal, face the possibility of losing much-needed funding if they fail to demonstrate that they are collecting sufficient operations revenue and are punishing those who do not pay their bills by disconnecting them. This occurs in an already economically stressed environment of limited revenues and local employment 
opportunities. In this way, local people are drawn into occupying social relations of domination: the enforcement of bill collections and service disconnections using these technologies of governance.

Seen from this perspective, participatory strategies in development, planning, and the management of treated water and sanitation systems are mechanisms through which neoliberal social relations are established around the priorities of cost-recovery and accountability. Involving community members in water management thus contributes to processes of domination from within by establishing the administrative control, social relations, and desires necessary for the expansion of capitalism and bureaucratic state power. Participatory approaches are central to the de-politicization of these processes, since they avoid issues of power and politics as divisive obstacles (Cleaver 2001).

The problems around village water security and water treatment plants must be understood within these processes of governance and neoliberalism. The sustainability policies around the operations of water treatment systems place communities within the realm of calculation and comparison with other communities. In addition to treating water, water treatment plants produce "safe water," a scarce and expensive commodity whose access and quality are regulated from outside of the community at the same time that responsibility for water treatment and distribution are framed as local. The result is administrative control of households and community social relations through safe water.

This commodification currently occurs under the seemingly benign but ambiguous ideologies of socalled "community participation" and "sustainability" (both ecological and economic) that shape and signify social relations of domination from within a community. Although the pricing of this commodity occurs at the local level, the very fact of its commodification is something that is required from without, made necessary by the technological inputs required for the successful operations and maintenance of water treatment systems and their dependence on external commodities including fuel. Further, limitations on community participation and local knowledge are structured from without. The inequalities of development, decision-making, and the standards by which Alaska Native villages are evaluated (compared to non-Native communities) are recognized locally, captured clearly in the statement of Qimmiurat's mayor:

If I went to Anchorage and told them there that they had to live in flush haul and dump their own sewage, they'd go crazy... But that's the difference between us and them. We don't matter. [They think] we're just a bunch of 'dumb Eskimos.'

Thus, water and sanitation programs must be understood from their inception as both public health projects and as ideological projects, part of a larger historical struggle around domination. Today that struggle focuses around sustainability. Highly significant in this struggle are the secondary, unintentional effects of water and sanitation projects: the establishing of governing relations within villages around sustainability, and the creation of subjectivities (water plant operators, and administrators) necessary for the management of safe water and the enforcement of hegemonic social relations of capitalism. Water treatment technologies do not simply transform raw water into safe water; they transform local social relations in ways that create and deepen inequalities and the processes of domination at the local level.

\section{References}

Agrawal, A. 2005. Environmentality: technologies of government and the making of subjects. Durham, NC: Duke University Press.

Alaska Department of Health. 1943. Not such good old days - nor very good present ones either: random quotations from the book, Dog Team Apostles by A.H. Savage. Alaska's Health 1: 5.

Alaska Department of Health. 1957. Study cases of death of Alaska infants. Alaska's Health 14: 1-2.

Allison, M. C. 2002. Balancing responsibility for sanitation. Social Science and Medicine 55: 1539-1551.

Althusser, L. 2006 [1971]. Ideology and ideological state apparatuses (notes towards an investigation). In A. Sharma and A. Gupta (eds.) The anthropology of the state: a reader. Malden, MA: Blackwell Publishing. Pp. 86-111.

American Public Health Association. 1984. National arctic health science policy. American Public Health Association, National Arctic Health Science Policy Task Force.

Bakker, K. 2002. From state to market? water mercantilización in Spain. Environment and Planning A 34: 767-790.

Bakker, K. 2004. An uncooperative commodity: privatizing water in England and Wales. Oxford, UK: Oxford University Press.

Bakker, K. 2007. The "commons" versus the "commodity": alter-globalization, anti-privatization and the human right to water in the global south. Antipode 39: 430-455.

Berardi, G. 1998a. Application of participatory rural appraisal in Alaska. Human Organization 57: 438-446.

Berardi, G. 1998b. Natural resource policy, unforgiving geographies, and persistent poverty in Alaska Native villages. Natural Resources Journal 38: 85-108.

Berardi, G. 1999. Schools, settlement, and sanitation in Alaska native villages. Ethnohistory 46: 329-360. 
Bergman, A.B., D.C. Grossman, A.M. Erdrich, J.G. Todd, and R. Forquera. 1999. A political history of the Indian Health Service. The Milbank Quarterly 77: 571-604.

Blackman, M. B. 1992. Sadie Brower Neakok: an Inupiaq woman. Seattle: University of Washington Press.

Buck, C. E., and G. Hays. 1943. Public health needs in Alaska. Alaska's Health 1: 3-15.

Budds, J. 2004. Power, nature and neoliberalism: the political ecology of water in Chile. Singapore Journal of Tropical Geography 25: 322-342.

Case, D. S., and D. A. Voluck. 2002. Alaska natives and American laws, 2nd edition. Fairbanks: University of Alaska Press.

Chambers, M. K., M. R. Ford, D. M. White, D. L. Barnes, and S. Schiewer. 2008. Distribution and transport of fecal bacteria at spring thaw in a rural Alaskan community. Journal of Cold Regions Engineering 22:16-37.

Chambers, M. K., M. R. Ford, D. M. White, D. L. Barnes, and S. Schiewer. 2009. Transport of fecal bacteria by boots and vehicle tires in a rural Alaskan community. Journal of Environmental Management 90: 961-966.

Chance, N. A. 1990. The Iñupiat and arctic Alaska: an ethnography of development. Fort Worth: Holt Rinehart and Winston.

Cleaver, F. 2001. Institutions, agency and the limitations of participatory approaches to development. In Participation: the new tyranny? Edited by B. Cooke and U. Kothari, pp. 36-55. New York: Zed Books.

Colt, S., S. Goldsmith, and A. Wiita. 2003. Sustainable Utilities in Rural Alaska Effective Management, Maintenance, and Operation of Electric, Water, Sewer, Bulk Fuel, Solid Waste Final Report. Anchorage, AK: Institute of Social and Economic Research.

Cooke, B., and U. Kothari. 2001. Participation: the new tyranny? New York: Zed Books.

Dombrowski, K. 2001. Against culture: development, politics, and religion in Indian Alaska. Lincoln: University of Nebraska Press.

Ducker, J. H. 1996. Out of harm's way: relocating Northwest Alaska Eskimos, 1907-1917. American Indian Culture and Research Journal 20: 43-71.

Eichelberger, L.P. 2010. Living in utility scarcity: energy and water insecurity in Northwest Alaska. American Journal of Public Health 100: 1010-8.

Eichelberger, L.P. 2011. Manufacturing insecurity: power, water, waste, and the silences of sustainability and suffering in Northwest Alaska. Ph.D. dissertation. Tucson: University of Arizona.

Elmendorf, M. L., and R. B. Isely. 1983. Public and private roles of women in water supply and sanitation programs. Human Organization 42: 195-204.

Environmental Protection Agency. 1995. Federal field work group report to Congress on Alaska rural sanitation. Seattle WA: U.S. Government Printing Office, Environmental Protection Agency Water Division 910/R-95-002.

Esteva, G. 2003. Development. In W. Sachs (ed.) The Development Dictionary, A Guide to Knowledge as Power. New Jersey: Zed Books. Pp. 6-25.

Ferguson, J. 1990. The anti-politics machine: 'development,' depoliticization, and bureaucratic power in Lesotho. New York: Cambridge University Press.

Fortuine, R. 2006. A century of adventure in northern health: the Public Health Service Commissioned Corps in Alaska 1879-1978. Landover, MD: The PHS Commissioned Officers Foundation for the Advancement of Public Health.

Fraser, N., and L. Gordon. 1994. A genealogy of dependency: Tracing a keyword of the U.S. welfare state. Signs 19: 309-336.

Giglioli, I., and E. Swyngedouw. 2008. Let's drink to the great thirst! water and the politics of fractured techno-natures in Sicily. International Journal of Urban and Regional Research 32: 392-414.

Haley, S. 2000. Evaluation of the Alaska Native Health Board sanitation facility operation and maintenance program: final report on phase III volume II. Anchorage, AK: University of Alaska, Institute of Social and Economic Research.

Hall, S. 1977. Culture, the media and the 'ideological effect'. In J. Curran, M. Gurevitch, and J. Woollacott (eds.). Mass communication and society. London: E. Arnold. Pp. 315-48.

Harvey, D. 2007. A brief history of neoliberalism. New York: Oxford University Press.

Hennessy, T. W., T. Ritter, R. C. Holman, D. L. Bruden, K. L. Yorita, L. Bulkow, J. E. Cheek, R. J. Singleton, and J. Smith. 2008. The relationship between in-home water service and the risk of respiratory tract, skin, and gastrointestinal tract infections among rural Alaska natives. American Journal of Public Health 98: 2072-8.

Hooper, C. L. 1881. Report of the cruise of the U.S. revenue-steamer Corwin in the Arctic ocean. Washington, DC: Government Printing Office. 
Howard, G., and J. Bartram. 2003. Domestic water quantity, service, level and health. Geneva, Switzerland: World Health Organization WHO/SDE/WSH/03.02.

Huskey, L. 1992. The economy of village Alaska. Anchorage, Alaska: University of Alaska, Institute of Social and Economic Research.

Johnston, B. R. 2005. The commodification of water and the human dimensions of manufactured scarcity. In L. M. Whiteford and S. Whiteford (eds.). Globalization, water, \& health: resource management in times of scarcity. Santa Fe: School of American Research Press. Pp. 133-152.

Jorgensen, J. G. 1996. Comment: recent twists and turns in American Indian health care. American Journal of Public Health 86: 1362-1364.

Knapp, G., and L. Huskey. 1988. Effects of transfers on remote regional economies: the transfer economy in rural Alaska. Growth and Change Spring: 25-39.

Kohl, B. 2002. Stabilizing neoliberalism in Bolivia: popular participation and privatization. Political Geography 21: 449-472.

Kothari, U. 2001. Power, knowledge and social control in participatory development. In B. Cooke and U. Kothari (eds.) Participation: the new tyranny? New York: Zed Books. Pp. 139-152.

Krauss, M., G. Holton, J. Kerr, and C. T. West. 2011. Indigenous Peoples and Languages of Alaska. Fairbanks and Anchorage: Alaska Native Language Center and UAA Institute of Social and Economic Research.

Kruse, J., and K. Foster. 1986. Changes in rural Alaska settlement patterns. Alaska Review of Social and Economic Conditions 23: 1-19.

Kunitz, S. J. 1996. The history and politics of US health care policy for American Indians and Alaskan Natives. American Journal of Public Health 86: 1464-73.

Leask, L. 1983. Effects of oil revenues on state aid to local government in Alaska. Alaska Review of Social and Economic Conditions 20: 1-19.

Li, T. 2007. The will to improve: governmentality, development, and the practice of politics. Durham: Duke University Press.

Marino, E., D. White, P. Schweitzer, M. Chambers, and J. Wisniewski. 2009. Drinking water in northwestern Alaska: using or not using centralized water systems in two rural communities. Arctic 62: 75-82

McBeath, G. A., and T. A. Morehouse. 1994. Political economy: myths and realities. In McBeath, G. A., and T. A. Morehouse (eds.) Alaska politics and government. Lincoln: University of Nebraska Press. Pp. 51-74.

Mitchell, D. 2001. Take my land, take my life: the story of Congress's historic settlement of Alaska native land claims, 1960-1971. Fairbanks, AK: University of Alaska Press.

Mitchell, T. 2002. Rule of experts: Egypt, techno-politics, modernity. Berkeley, CA: University of California Press.

Morrow, P., and C. Hensel. 1992. Hidden dissension: minority-majority relationships and the use of contested terminology. Arctic Anthropology 29: 38-53.

Murkowski, F. 2005. Administrative Order No. 224. Juneau: State of Alaska, Office of the Governor.

Nadasdy, P. 2000. The politics of TEK: power and the 'integration' of knowledge. Arctic Anthropology 36:118.

Nixon, R. M. 1970. Message from the President of the United States transmitting recommendations for Indian policy. 91st Congress, 2nd session, H Doc 91-363.

Oswalt, W. H. 1967. Alaskan Eskimos. Scranton, PA: Chandler Publishing Company.

Page, B. 2005. Paying for water and the geography of commodities. Transactions of the Institute of British Geographers 30: 293-306.

Pearce, M., E. Willis, and T. Jenkin. 2007. Aboriginal people's attitudes towards paying for water in a waterscarce region of Australia. Environment, Development and Sustainability 9: 21-32.

Roncoli, C. 2010. Participatory models and exclusionary frames in water management. Anthropology News 51: $12-13$.

Saylor, B., and S. Haley. 2007. Effects of rising utility costs on household budgets, 2000-2006. University of Alaska: Institute of Social and Economic Research.

Schofield, B. 2002. Partners in power: governing the self-sustaining community. Sociology 36: 663-683.

Scott, J. C. 1985. Weapons of the weak: everyday forms of peasant resistance. New Haven: Yale University Press.

Scott, J. C. 1998. Seeing like a state: how certain schemes to improve the human condition have failed. New Haven: Yale University Press.

Sider, G. 1988. Culture and class in anthropology and history: a Newfoundland illustration. New York: Cambridge University Press. 
Spencer, R. F. 1984. North Alaska Eskimo: introduction. In D. Damas (ed.). Handbook of North American Indians, vol. 5. Washington D.C.: Smithsonian Institution. Pp. 278-284.

Stanley, W. R. 1990. Socioeconomic impact of oil in Nigeria. GeoJournal 22: 67-79.

State of Alaska. 1972. Village Safe Water Act. Juneau, AK: State of Alaska Legislature, AS 46.07.010.

Swyngedouw, E. 2004. Social power and the urbanization of water: flows of power. Oxford; New York: Oxford University Press.

U.S. Congress. 1994. An Alaskan challenge: native village sanitation. Washington, DC: Office of Technology Assessment, U.S. Government Printing Office.

Ullrich, O. 1992. Technology. In W. Sachs (ed.) The development dictionary: a guide to knowledge as power. New Jersey: Zed Books. Pp. 275-287.

Village Safe Water. 2005. Alaska Department of Environmental Conservation Village Safe Water Program. http://www.dec.state.ak.us/water/vsw/pdfs/vswbrief.pdf [accessed January 22, 2010].

von Schnitzler, A. 2008. Citizenship prepaid: water, calculability, and techno-politics in South Africa. Journal of Southern African Studies 34: 899-917.

Wade, S., S. Modrow, and J. Kane. 2007. Rural utility business advisor program evaluation. Prepared for the State of Alaska Department of Commerce, Community, and Economic Development, Division of Community Advocacy. Anchorage, AK: Information Insights, Inc.

Wenger, J. D., T. Zulz, D. Bruden, R. Singleton, M. G. Bruce, L. Bulkow, D. Parks, K. Rudolph, D. Hurlburt, T. Ritter, J. Klejka, and T. Hennessy. 2010. Invasive pneumococcal disease in Alaskan children: impact of the seven-valent pneumococcal conjugate vaccine and the role of water supply. Pediatric Infectious Disease Journal 29: 251-6.

Whiteford, L. M., and S. Whiteford. 2005. Paradigm change. In L. M. Whiteford and S. Whiteford (eds.) Globalization, water, \& health: resource management in times of scarcity. Santa Fe: School of American Research Press. Pp. 3-23.

Whiteford, S., and A. Cortez-Lara. 2005. Good to the last drop: the political ecology of water and health on the border. In L.M. Whiteford and S. Whiteford (eds.) Globalization, water, \& health: resource management in times of scarcity. Santa Fe: School of American Research Press. Pp. 231-254.

Wiita, A., and S. Haley. 2003. Evaluation of the U.S. Army Corps of Engineers' water and sanitation project in the village of Buckland, Alaska Phase 2. Institute of Social and Economic Research.

Yapa, L. 1996. Improved seeds and constructed scarcity. In R. Peet and M. Watts (eds.) Liberation ecologies: environment, development, social movements. New York: Routledge. Pp. 69-85. 


\begin{abstract}
This paper critically examines sustainability as an ideology that gives meaning to processes of domination occurring through the operations of treated water systems in Iñupiaq villages in Alaska's Northwest. The implementation of neoliberal sustainability policies shapes social relations around water, establishes particular forms of 'expert' knowledge, erases experiences of water insecurity, and renders moot local opposition to charging for water. Throughout, treated 'safe water' is signified as a scarce commodity; its production requiring full cost recovery through practices of calculation that discipline Iñupiaq citizens as consumers. This paper provides a case study for understanding some of the processes of domination through which the commodification of water occurs, and how local people who otherwise oppose these processes may nonetheless become drawn into practices of calculation and domination in an attempt to meet state-defined sustainability requirements.
\end{abstract}

Key words: Sustainability, water insecurity, domination, Alaska Natives

\title{
Résumé
}

Ce document examine la durabilité (sustainability) comme une idéologie qui donne un sens à des processus de domination. Ils se produisent dans les opérations de systèmes d'eau traitée dans les villages Iñupiaq du NordOuest de l'Alaska. La mise en œuvre des politiques de développement durable néolibérales formes de relations sociales autour de l'eau; établit des formes particulières des connaissances «l'expert», efface les expériences de l'insécurité de l'eau, et dilue l'opposition locale à la tarification de l'eau. «Eau potable» traité est considérée comme rare; sa production nécessitant recouvrement intégral des coûts, grâce à des pratiques de calcul que les Iñupiaq se transforment en consommateurs. Cet article fournit une étude de cas pour comprendre certains des processus de domination à travers lequel la marchandisation de l'eau se produit. Il examine également comment les populations locales qui, autrement, s'opposent à ces processus, peuvent quand même devenir établi dans les pratiques de calcul et de domination dans une tentative pour répondre aux exigences de durabilité définis par l'état.

Mots clés: développement durable, l'insécurité de l'eau, la domination, communautés inuits de l'Alaska

\section{Resumen}

Esta investigación examina de manera crítica la sustentabilidad como una ideología que le da sentido a los procesos de control que se presentan en las operaciones de los sistemas de agua tratada en los poblados Iñupiaq en el noroeste de Alaska. La implementación de políticas neoliberales de sustentabilidad determina las relaciones sociales concernientes al agua, establece formas particulares de conocimiento "experto," borra las experiencias sobre inseguridad de agua y plantea una oposición discutible a nivel local para cobrar por la misma. Desde el principio hasta el fin, el "agua segura" tratada se ha definido como un producto escaso; su producción requiere una recuperación del costo total a través de prácticas de cálculo que castigan a los ciudadanos Iñupiaq, como consumidores. Esta investigación brinda un estudio de caso para comprender algunos de los procesos de control mediante los cuales se da la comercialización del agua y de cómo las personas de la localidad que de otra manera se oponen a estos procesos, pueden no obstante, involucrarse en estas prácticas de cálculo y dominio en un intento por satisfacer los requisitos de sustentabilidad definidos por el estado.

Palabras clave: Sustentabilidad, inseguridad de agua, dominio, indígenas de Alaska 